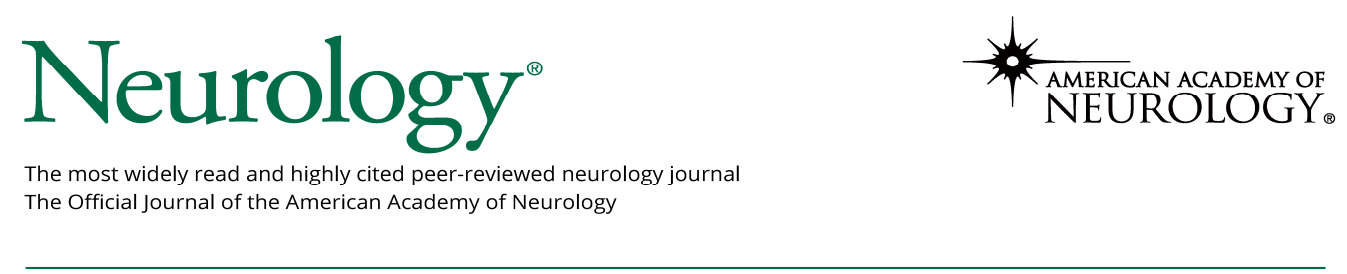

Neurology Publish Ahead of Print

DOI: 10.1212/WNL.0000000000012614

\title{
Teaching NeuroImages: Bilateral Nucleus Tractus Solitarius Lesions in Neurogenic
} Respiratory Failure

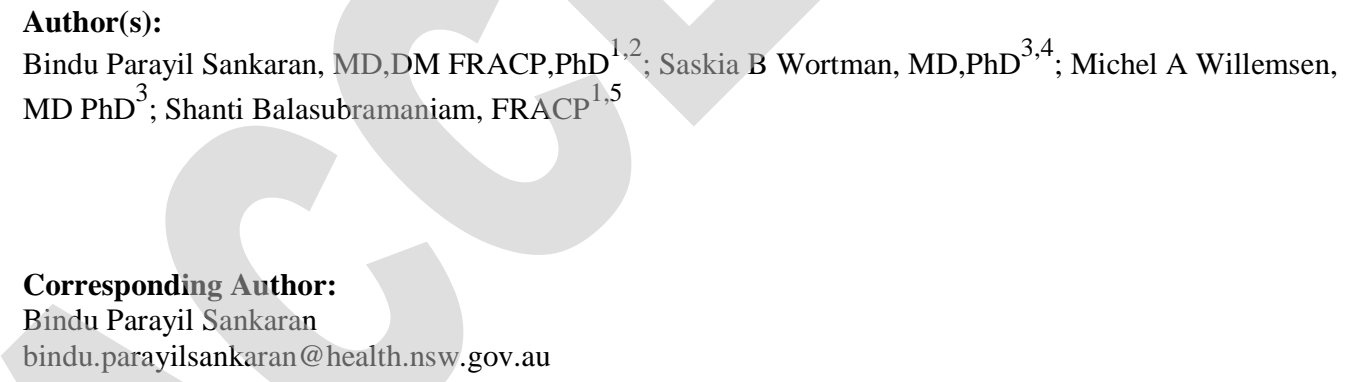

Neurology ${ }^{\circledR}$ Published Ahead of Print articles have been peer reviewed and accepted for publication. This manuscript will be published in its final form after copyediting, page composition, and review of proofs. Errors that could affect the content may be corrected during these processes. 
Affiliation Information for All Authors: 1. Genetic Metabolic Disorders Service, Western Sydney Genetics Program, The Children s Hospital at Westmead, Sydney, NSW, Australia; 2. The Children's Hospital at Westmead Clinical School, Sydney Medical School, The Faculty of Medicine and Health, The University of Sydney; Saskia B Wortmann; 3. Department of Pediatric Neurology, Amalia Children s Hospital, Radboud University Nijmegen Medical Center, Nijmegen, The Netherlands; 4.Department of Pediatrics, University Children s Hospital, Salzburg, Austria; 5. Discipline of Genetic Medicine, Sydney Medical School, University of Sydney, Sydney, NSW, Australia.

\section{Contributions:}

Bindu Parayil Sankaran: Drafting/revision of the manuscript for content, including medical writing for content; Major role in the acquisition of data; Study concept or design; Analysis or interpretation of data Saskia B Wortman: Drafting/revision of the manuscript for content, including medical writing for content; Major role in the acquisition of data; Study concept or design; Analysis or interpretation of data Michel A Willemsen: Drafting/revision of the manuscript for content, including medical writing for content; Major role in the acquisition of data; Study concept or design; Analysis or interpretation of data Shanti Balasubramaniam: Drafting/revision of the manuscript for content, including medical writing for content; Major role in the acquisition of data; Study concept or design; Analysis or interpretation of data

Number of characters in title: 100

Abstract Word count:

Word count of main text: 100

References: 2

Figures: 1

Tables: 0

Neuroimage Legend Count: 50

Search Terms: [ 96 ] Mitochondrial disorders, [ 120 ] MRI, [ 153 ] Metabolic disease (inherited), [ 227 ]

All Pediatric

Study Funding: The authors report no targeted funding

Disclosures: B.Parayil Sankaran reports receipt of the clinical research fellowship from Mito Foundation Australia. S.B Wortmann reports no disclosures relevant to the manuscript.M.A Willemsen reports no disclosures relevant to the manuscript. S.Balalsubramaniam reports no disclosures relevant to the manuscript.

A 7-year-old girl with MEGD(H)EL [3- Methylglutaconic aciduria, dystonia-deafness, (hepatopathy), encephalopathy, Leigh-like syndrome, SERAC1][1] presented with worsening respiratory compromise. The evaluation showed type II respiratory failure (e.g., hypercapnic) necessitating mechanical ventilation. Cerebral MRI demonstrated progression of known changes in MEGD(H)EL (Fig A\&B) and symmetric nucleus tractus solitarius (NTS) involvement (Fig C\&D). She was ventilator dependent and subsequently succumbed to the disease.

Bilateral NTS involvement is a rare occurrence in a neurological setting.[2] NTS plays a crucial role in the continuous modulation of chemoreceptor mediated respiration and other respiratory reflexes.[2] This case illustrates the neuroimaging correlate of central neurogenic respiratory failure. 
Teaching Slides-http://links.lww.com/WNL/B485

\section{References}

1. Wortmann SB, van Hasselt PM, Baric I, et al. Eyes on MEGDEL: distinctive basal ganglia involvement in dystonia deafness syndrome. Neuropediatrics. 2015;46(2):98103.

2. Cutsforth-Gregory JK, Benarroch EE. Nucleus of the solitary tract, medullary reflexes, and clinical implications. Neurology. 2017;88(12):1187-1196.

\section{Title and legend to the figure:}

\section{Figure: Brain MRI}

Brain MRI at age 2 years shows the classical 'putaminal eye' sign (A-arrows). MRI at age 7 years shows progressive atrophy and gliosis of basal ganglia and cortical atrophy (B) and bilateral symmetrical signal changes of the nucleus tractus solitarius on FLAIR (C-arrows) and T2-weighted images (D-arrows)

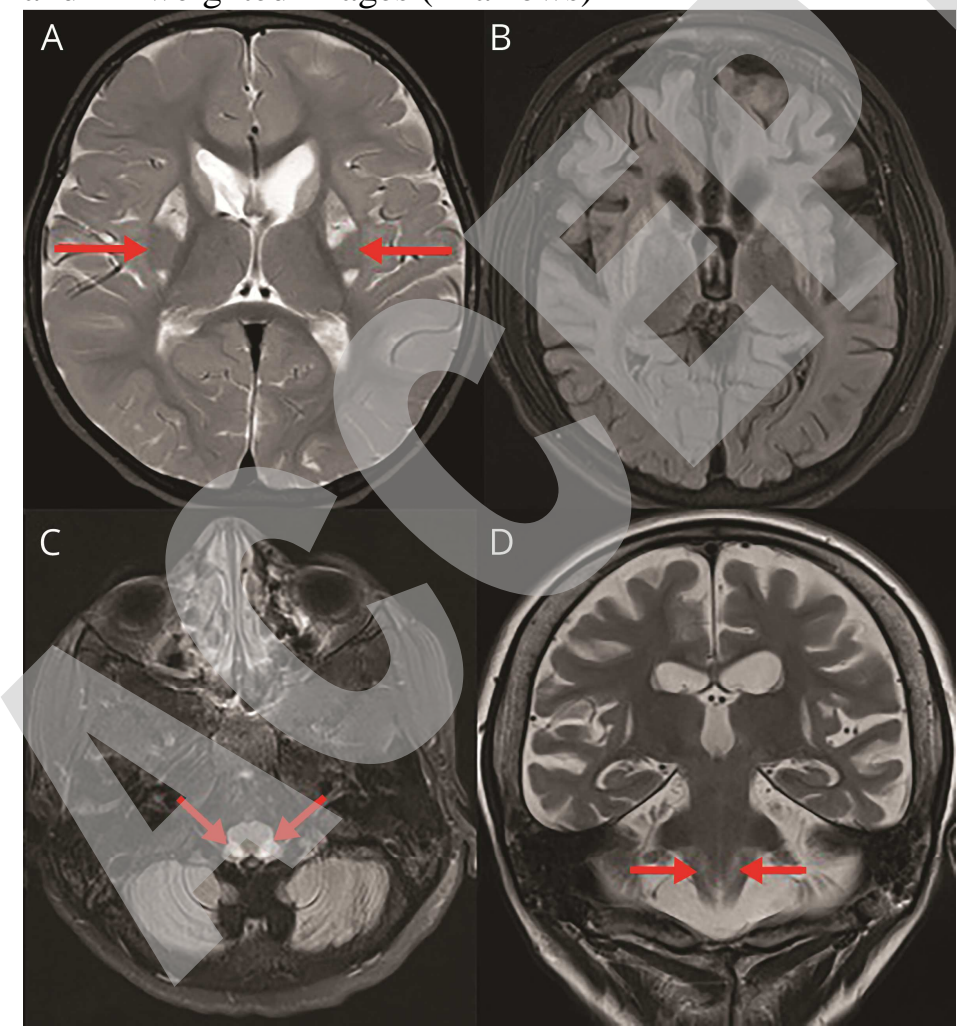




\section{Appendix 1.}

\begin{tabular}{|c|c|c|}
\hline Name & Location & Contribution \\
\hline $\begin{array}{l}\text { Bindu Parayil } \\
\text { Sankaran MD DM } \\
\text { FRACP PhD }\end{array}$ & $\begin{array}{l}\text { Children's Hospital at } \\
\text { Westmead NSW } \\
\text { Australia }\end{array}$ & $\begin{array}{l}\text { Designed and } \\
\text { conceptualized } \\
\text { study; analyzed and } \\
\text { interpreted the data; } \\
\text { drafted the } \\
\text { manuscript for } \\
\text { intellectual } \\
\text { content }\end{array}$ \\
\hline $\begin{array}{l}\text { Saskia B Wortmann } \\
\text { MD PhD }\end{array}$ & $\begin{array}{l}\text { Amalia Children's } \\
\text { Hospital, Nijmegen, } \\
\text { The Netherlands and } \\
\text { Department of } \\
\text { Pediatrics, University } \\
\text { Children's Hospital, } \\
\text { Salzburg, Austria }\end{array}$ & $\begin{array}{l}\text { Designed and } \\
\text { conceptualized } \\
\text { study; analyzed and } \\
\text { interpreted the data; } \\
\text { drafted the } \\
\text { manuscript for } \\
\text { intellectual } \\
\text { content }\end{array}$ \\
\hline $\begin{array}{l}\text { Michel A } \\
\text { Willemsen MD PhD }\end{array}$ & $\begin{array}{l}\text { Amalia Children's } \\
\text { Hospital, Nijmegen, } \\
\text { The Netherlands }\end{array}$ & $\begin{array}{l}\text { Designed and } \\
\text { conceptualized } \\
\text { study; analyzed and } \\
\text { interpreted the data; } \\
\text { drafted the } \\
\text { manuscript for } \\
\text { intellectual } \\
\text { content }\end{array}$ \\
\hline $\begin{array}{l}\text { Shanti } \\
\text { Balasubramaniam } \\
\text { FRACP }\end{array}$ & $\begin{array}{l}\text { Children's Hospital at } \\
\text { Westmead NSW } \\
\text { Australia }\end{array}$ & $\begin{array}{l}\text { Designed and } \\
\text { conceptualized } \\
\text { study; analyzed and } \\
\text { interpreted the data; } \\
\text { drafted the } \\
\text { manuscript for } \\
\text { intellectual } \\
\text { content }\end{array}$ \\
\hline
\end{tabular}




\section{Neurology}

\section{Teaching NeuroImages: Bilateral Nucleus Tractus Solitarius Lesions in Neurogenic Respiratory Failure}

Bindu Parayil Sankaran, Saskia B Wortman, Michel A Willemsen, et al.

Neurology published online August 10, 2021

DOI 10.1212/WNL.0000000000012614

\section{This information is current as of August 10, 2021}

Updated Information \&

Services

Subspecialty Collections

Permissions \& Licensing

Reprints including high resolution figures, can be found at:

http://n.neurology.org/content/early/2021/08/10/WNL.0000000000012614. citation.full

This article, along with others on similar topics, appears in the following collection(s):

All Pediatric

http://n.neurology.org/cgi/collection/all_pediatric

Metabolic disease (inherited)

http://n.neurology.org/cgi/collection/metabolic_disease_inherited

Mitochondrial disorders

http://n.neurology.org/cgi/collection/mitochondrial_disorders

MRI

http://n.neurology.org/cgi/collection/mri

Information about reproducing this article in parts (figures,tables) or in its entirety can be found online at:

http://www.neurology.org/about/about_the_journal\#permissions

Information about ordering reprints can be found online:

http://n.neurology.org/subscribers/advertise

Neurology $\AA^{\circledR}$ is the official journal of the American Academy of Neurology. Published continuously since 1951, it is now a weekly with 48 issues per year. Copyright (C) 2021 American Academy of Neurology. All rights reserved. Print ISSN: 0028-3878. Online ISSN: 1526-632X.

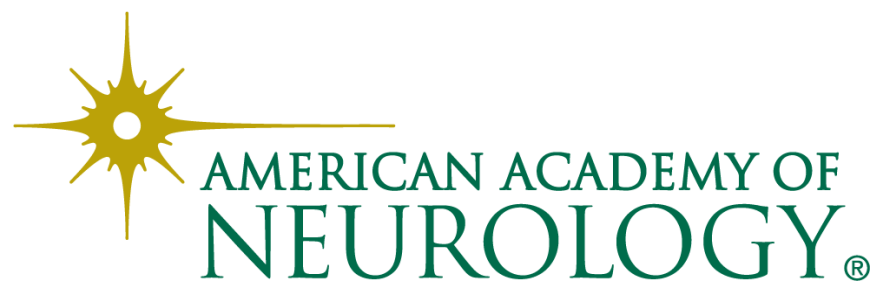

